\title{
Knowledge and attitude about mental illness among nursing students
}

\author{
Shrestha $\mathrm{MR}^{*}$ \\ Senior Consultant Neuropsychiatrist, Mental hospital, Lagankhel, Lalitpur, Nepal. \\ E-mail *Corresponding author: drmohanrajshrestha@hotmail.com
}

\begin{abstract}
Introduction: Although recent advances in psychiatry have increased our understanding of psychiatric disorders, many people may be unaware about mental illness and its treatment. The negative attitude is known hindrance to providing quality service to mental ill people. The aim of this study is to assess the knowledge and attitude about mental illness among nursing students.

Method: The study was carried out in mental hospital, Lagankhel, Nepal. All one hundred eight nursing students posted for psychiatric posting for two weeks formed the study population. A structured standard questionnaire was supplied to the students at the first day of posting for their responses.

Results: It was a purposive, descriptive study with 108 respondents of age group 15-20 (85.1\%). The study revealed that $97.2 \%$ of the respondents thought that all mentally ill patients are not mad. The majority had showed their knowledge about cause of mental illness as genetic (78.6\%) and biochemical disturbances (97.2\%). Respondents expressed their faith in psychiatrist (96.3\%) but less in faith healers (19.4\%).
\end{abstract}

Conclusion: This study revealed that there was overall adequate knowledge and by large a positive attitude towards mentally ill people among the nursing students.

Keywords: Attitude, knowledge, mental illness, nursing students.

\section{INTRODUCTION}

Considering their prevalence, their tendency to manifest high continuity and general difficulties in their treatment, mental disorders constitute a major public health problem. Today the global life long prevalence for any given psychiatric disorders is reported to be as high as $48 \%^{1}$. In other words, it is estimated that there are at least 450 million people in the world currently suffering from some kind of mental disorders, with 150 million affected by depression and 25 million by schizophrenia ${ }^{2}$.

Attitudes influence both professional and personal behavior. In particular stigma and discrimination associated with mental illness and expressed by mental health professionals as well as the general public, results in the underuse of mental health services ${ }^{3}$. The word stigma comes from the Greek word "stizen" which means to tattoo or to brand. Broadly speaking stigma is a negative evaluation of person tainted or discredited on the basis of attributes such as mental disorder or mental illness race, ethnicity, drug misuse or physical disability4. Society's attitude towards mental illness directly affects patient's awareness of the disorder in question, their search for medical care, communication with doctors and whole process of therapy and rehabilitation ${ }^{5}$. Incomplete knowledge, misinformation and stigmatization have a direct negative impact on 
early diagnosis of the disorder and the commencement of therapy at an early stage ${ }^{6}$.

As early psychiatric intervention is known to reduce morbidity and mortality in the patients with physical illness, the needs for an early referral to psychiatric services is not overemphasized. The nurse's role in this regard is being increasingly recognized7. In addition to that, the knowledge, attitude and beliefs of nursing staff regarding mental illness will be key, as they are directly involved in providing mental health care along with general care to needy physically and psychologically ill patients. The aim of this present study is to assess proficiency certificate level nursing student's knowledge and attitudes towards mental illness

\section{RESULT}

The majority of the students were from young age group 15- 20 years. Majority of the cases were unmarried. Most of the cases were from nuclear family $88(81.5 \%)$. Among them, Hindus were $95.4 \%$ and Buddhist $3.7 \%$. Majority of them $\mathbf{( 9 1 . 7 \% )}$ were of middle socio-economic status.

Table 1.Socio- demographic profile

\begin{tabular}{cl}
\multicolumn{1}{c}{$\begin{array}{c}\text { AGE GROUP } \\
\text { (YEARS) }\end{array}$} & NO OF CASES (\%) \\
\hline $15-20$ & $92(85.19)$ \\
\hline $20-25$ & $13(12.03)$ \\
\hline $7-25$ & $3(2.78)$ \\
\hline Marital status & $5(4.6)$ \\
\hline Married & $102(94.4)$ \\
\hline Unmarried & $1(1.0)$ \\
\hline Separated & $88(81.5)$ \\
\hline Family type & $17(15.7)$ \\
\hline Nuclear & $3(2.8)$ \\
\hline Joint & \\
\hline Extended & \\
\hline $\begin{array}{l}\text { Socio-economic } \\
\text { status } \quad \text { Lower }\end{array}$ \\
\hline Middle & $9(8.3)$ \\
\hline Upper & $0(0)$ \\
\hline Religion & $103(95.4)$ \\
\hline Hindu & $4(3.7)$ \\
\hline Buddhist & $1(0.9)$ \\
\hline Muslim & \\
\hline & \\
\hline
\end{tabular}

Majority of the respondents regarded that mental patients can present with physical symptoms. The majority did not believe that all mentally ill patients are mad. Most of the respondents believed that mental illness is treatable and most of them would not discriminate the mentally ill person.

Table 2. General perception regarding mental illness

\begin{tabular}{|c|c|c|c|}
\hline \multirow[t]{2}{*}{$\begin{array}{l}\text { QUESTION } \\
\text { ASKED }\end{array}$} & \multicolumn{3}{|c|}{ RESPONSES (\%) } \\
\hline & YES & NO & $\begin{array}{l}\text { DO NOT } \\
\text { KNOW }\end{array}$ \\
\hline $\begin{array}{l}\text { Mental illness is } \\
\text { contagious. }\end{array}$ & 10.2 & 87.0 & 2.8 \\
\hline $\begin{array}{l}\text { Mental illness is } \\
\text { not treatable. }\end{array}$ & 2.8 & 96.3 & 0.9 \\
\hline $\begin{array}{l}\text { It is always } \\
\text { necessary to admit } \\
\text { mental patients to } \\
\text { a mental hospital. }\end{array}$ & 13.9 & 86.1 & 0 \\
\hline $\begin{array}{l}\text { All mentally ill } \\
\text { patients are mad. }\end{array}$ & 1.9 & 96.2 & 0.9 \\
\hline $\begin{array}{l}\text { Mental patients } \\
\text { can present with } \\
\text { physical } \\
\text { symptoms. }\end{array}$ & 78.7 & 17.6 & 3.7 \\
\hline $\begin{array}{lr}\text { Would } & \text { you } \\
\text { discriminate } & \text { the } \\
\text { mentally } & \text { ill } \\
\text { persons? } & \end{array}$ & 3.7 & 94.4 & 1.9 \\
\hline
\end{tabular}

The majority of the respondents believe that mental illness could be caused by financial constraint, genetic heritability and biochemical disturbances. Respondents did not believe that own sin, evil spirits/ghost/witchcrafts/black magic could cause mental illness.

Most of the respondents opined that mentally ill people should be treated by a psychiatrist and majority of them believed that mentally ill person are also in need of treatment as patients with physical illness. A large majority of respondents expressed yoga and meditation could be effective for treatment. 
Table 3. Knowledge about etiology

\begin{tabular}{llll} 
QUESTION & \multicolumn{2}{c}{ RESPONSE (\%) } \\
\cline { 2 - 4 } ASKED & Yes & No & $\begin{array}{l}\text { Do not } \\
\text { Know }\end{array}$ \\
\hline $\begin{array}{l}\text { Mental illness is } \\
\text { due to }\end{array}$ & & & \\
\hline $\begin{array}{l}\text { Own sin / } \\
\begin{array}{l}\text { Disregard of } \\
\text { religion }\end{array}\end{array}$ & 10.2 & 72.2 & 17.6 \\
\hline $\begin{array}{l}\text { Evil spirits / Ghost } \\
\text { / Witch craft / } \\
\text { Black magic }\end{array}$ & 32.4 & 62.0 & 5.6 \\
\hline $\begin{array}{l}\text { Financial } \\
\text { constraints }\end{array}$ & 91.7 & 6.5 & 1.9 \\
\hline $\begin{array}{l}\text { Genetic } \\
\text { hereditability }\end{array}$ & 78.6 & 14.8 & 6.5 \\
\hline $\begin{array}{l}\text { Biochemical } \\
\text { disturbances in } \\
\text { brain }\end{array}$ & 97.2 & 1.9 & 0.9 \\
& & & \\
\hline
\end{tabular}

Table 4. Knowledge and belief about treatment:

\begin{tabular}{|c|c|c|c|c|}
\hline \multirow{2}{*}{$\begin{array}{l}\text { QUESTION } \\
\text { ASKED }\end{array}$} & \multicolumn{4}{|c|}{ RESPONSES (\%) } \\
\hline & Yes & No & $\begin{array}{c}\text { Do } \\
\text { know }\end{array}$ & not \\
\hline $\begin{array}{lll}\begin{array}{l}\text { Following } \\
\text { effective }\end{array} & & \text { be } \\
\text { for } \\
\text { treatment }\end{array}$ & & & & \\
\hline Yoga and meditation & 96.3 & 1.9 & & 1.8 \\
\hline $\begin{array}{l}\text { Visiting local faith } \\
\text { healers }\end{array}$ & 19.4 & 61.4 & 19.5 & \\
\hline $\begin{array}{l}\text { Getting treated by } \\
\text { general practioner }\end{array}$ & 40.7 & 44.4 & 14.9 & \\
\hline $\begin{array}{l}\text { Mentally ill patients } \\
\text { are also in need of } \\
\text { treatment as patients } \\
\text { with physical illness }\end{array}$ & 86.1 & 12.0 & & 1.9 \\
\hline $\begin{array}{l}\text { Getting treated by } \\
\text { psychiatrist }\end{array}$ & 96.3 & 2.8 & & 0.9 \\
\hline
\end{tabular}

\section{DISCUSSION}

Mental health problems are of serious concern across the world. A major barrier to the realization of good mental health and well being is stigma and discrimination. Nurses working in general hospitals have an important role to play in dealing with patients having psychiatric problem. They help in referring patients to psychiatrist as they closely associated with patients and easily notice behavioral change in them.

The participants in this study were second year PCL nursing students who took the psychiatric / mental health course before posting in mental hospitals. Regarding etiology of mental illness, the vast majority held fairly good knowledge about it. Most of the respondents felt that God's curse, witch craft or evil spirit does not cause mental illness which again may be contrary to the general public's prevailing views but are comparable to the views of nurses in a study from India ${ }^{7}$. Such information might have been acquired from training. In developing countries more than western cultures, supernatural phenomena like witch craft and possession by evil spirits are seen as important cause of mental illness ${ }^{9}$. Subjects' belief in genetic heritability and biochemical disturbances in the brain indicated their better knowledge of the etiology of mental illness.

Majority $(91.7 \%)$ of the respondents correctly underscored the importance of psychosocial causes including financial constraint as cause of mental illness which is parallel with the opinion held by western population 10. The views expressed in this study are almost similar to the study done by Shyangwa et $\mathrm{al}^{8}$.

Regarding the treatment of mental illness (96.3\%) opined by those psychiatrists are most effective followed by yoga and meditation. In one western study psychiatrist and psychologist are rated less than general practioners for minor psychiatric problems but are more likely seen helpful for schizophrenia11. The study done by Shyangwa et $\mathrm{al}^{8}$ revealed that about $98.2 \%$ viewed that mentally ill patients are also in need of treatment as patients with physical illness which is similar to this findings.

Formal education and experiences are important vehicles to change the attitudes towards individuals with mental illness ${ }^{12}$. Previous researchers have shown that when participants are given accurate and enough information about mental illness, they have less negative attitude and less fear towards those individuals ${ }^{13}$. Changing the negative attitude of 
students towards mental illness will affect the quality of the patient care.

\section{CONCLUSION}

The majority of the respondents had fairly good knowledge about the cause of mental illness and accordingly they preferred possible effective modalities of treatment. Positive attitude of nursing students about the mental illness will influence the quality of care they deliver to the mental ill patients. Because of the mental health course provided for the students, their attitude towards mentally ill people was found to be positive. Attitudes are important in determining behaviors, so it is important for the educators to focus on nursing students' attitudes; as they are the future professionals.

\section{REFERENCE:}

1. Kaplan and sadock's comprehensive text book of psychiatry, eight editions. Sadock BJ and sadock VA editors Philadelphia: Lippincott Williams and Wilkins. 2005: 664 - 665.

2. World Health Organization. Investing in mental health. Department of mental health and substance Dependence. Non communicable disease and mental health. World health organization. Geneva, 2003.

3. Emrich K, Thompson TC ,Moore G. Positive attitudes an essential element for effective care of people with mental illnesses. Journal of psychosocial nursing and mental health services. 2003; 41 (5): 16 - 25.

4. Goff man E stigma: notes on the management of spoiled identities. 1963.
5. Sagduyu A, Aker T, Ozmen E et al. Relatives beliefs and attitudes towards schizophrenia. An epidemiological investigation, Turkish journal of psychiatry. 2003; 14: $203-212$.

6. Leaf PJ, Bruce MI, Tischler GL et al. The relationship between demographic factors and attitudes towards mental health service. Journal of community psychol. 1987; 15: 275 - 284.

7. Choudhary JR, Mandal A ,Bhattacharyya D. Indian journal of social psychiatry. 1995; 11: $43-47$.

8. Shyangwa PM, Khandelwal SK. Knowledge and attitude about mental illness among nursing student. Journal of Nepal medical association. 2003; 42: $27-31$.

9. Rizali SM, Khan UA and Hashanah CI. Belief in supernatural causes of mental illness among Malay patients: Impact on treatment. Acta psychiatrica scandinavica. 1996; 94: 229 - 233.

10. Matschinger $\mathrm{H}$, Angereyer M, Lay $\mathrm{C}$. Beliefs about the causes of mental disorders: A new methodological approach. Social psychiatry and psychiatry epidemiology. 1996; 31.

11. Jorn AF, Jacomb AE, korten $\mathrm{AE}$ et al. Mental health literacy. A survey of public's ability to recognize mental disorder and their beliefs about the effectiveness of treatment. Medical journal of Australia. 1997: 166: 182 - 186.

12. Anguilla L, Whitbournce $S$ and powers C. The effects of instruction and experiences on college student's attitudes toward the elderly. 1996; 22 : $483-495$.

13. Corrigan P, Green A, Lundin R et al. Familiarity with social distance from people who have a serious mental illness.2001; $\quad$ 562: $953 \quad$ - 958. 